\title{
Faculty Perceptions on Accessibility in Online Learning: Knowledge, Practice and Professional Development
}

\author{
Thelma C. Guilbaud, Florence Martin, and Xiaoxia Newton \\ University of North Carolina at Charlotte
}

\begin{abstract}
This study examined the level of readiness of faculty in designing and delivering accessible online courses to meet the needs of all learners, including students with disabilities. A total of 182 tenured/non-tenured full time, part-time, adjunct and clinical faculty from three public universities of different sizes were surveyed to gauge their awareness, understanding, and practices related to disability laws, quality standards, utilization of tools, and professional development support. Results from the study indicated an uneven level of readiness by faculty regarding online learning accessibility. Results from the study showed that professional development training in online learning had a very significant influence on accessibility knowledge and practice. Also, high perceptions of knowledge for institutional policy and terminology and low perception of accessibility laws and standards were found. It is also found that training on disability-related laws and regulations provided by higher education institutions was insufficient and at times, does not align with the faculty's schedule. Given the results of the study, it is recommended that higher education institutions reorient their approach to supporting faculty who teach online and develop a comprehensive strategy to reach the goal of helping all students, including students with disabilities, to fully engage online learning. The findings from this study have implications for course development and implementation to support students with disabilities.
\end{abstract}

Keywords: accessibility in online learning, faculty development, transformative learning, online learners with disabilities

Guilbaud, T.C., Martin, F., \& Newton, X. (2021). Faculty perception on accessibility in online learning: Knowledge, practice and professional development. Online Learning, 25(2), 635. https://doi.org/10.24059/olj.v25i2.2233 


\section{Faculty Perceptions on Accessibility in Online Learning: Knowledge, Practice and Professional Development}

In the past few years, there has been tremendous growth in online learning both in the U.S. and globally. Data from the National Center for Education Statistics (2019) reports that nearly 6 million students enrolled in an online course, an increase of $3.9 \%$ over the previous year's statistics in fall 2015. Further, recent data show that $25.9 \%$ of students in higher education institutions had taken distance education courses in 2012; that percentage reached $28.3 \%$ in 2014 (Allen \& Seaman, 2017).

A major advantage in online learning is that enrolled students may be physically located anywhere in the world. Instructors also have similar benefits in flexibility with time and location to deliver the online course when it works best for them. Among the increasing number of students in higher education, those students with disabilities pursuing post-secondary education and training has also been steadily rising in the past few years.

According to the most available data from the National Center for Education Statistics (2019), 19\% of undergraduate students in the 2015-16 academic year reported having a disability. Students with disabilities also have lower course completion rates compared to their non-disabled peers (Gladhart, 2010). While many steps have been taken to address the needs of students with disabilities who take courses on the traditional campus as presented by Huss \& Eastep (2016), accessibility in online education "has presented an immediate challenge and susceptibility for higher education institutions" (p.2).

Faculty who design the online courses are key to providing accessible learning environments that are inclusive of all learners (Betts, Cohen, Veit, Alphin \& Broadus, 2013; Burgstahler, 2003; Marchetti, 2011). Yet, many of the faculty development and student support units and departments at higher education institutions wrestle with finding ways to meet the academic needs of postsecondary students with disabilities in the online environment. Hence, there is a need to examine faculty perception based on their knowledge, practice, and professional development available on accessibility for online learning.

\section{Review of Relevant Literature}

This literature review offers the context and state of online delivery and learning in the United States, with a special focus on faculty knowledge, practices, and training support to meet the needs of learners with disabilities. The literature looks at three scholarship domains, designated as Macro, Meso, and Micro. As illustrated in Figure 1 below, the Macro domain focuses on the online learning landscape. Next, the Meso or middle layer of the review explores the law and institutional readiness on accessibility in online learning. Micro, the final domain of the review, examines the issues, approaches, and strategies that are directly connected to supporting online learners with disabilities. 


\section{Figure 1}

Structure of Literature Review (Guilbaud, 2019)

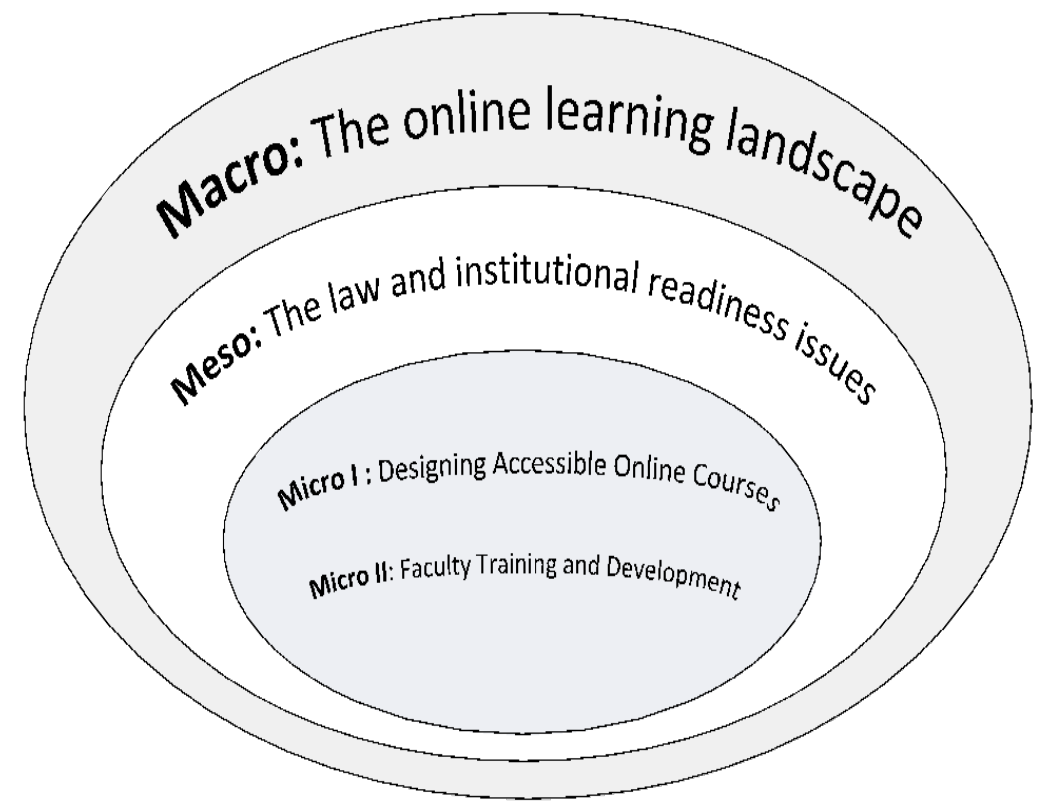

As part of the Macro domain, the research explores current issues related to the rise of online learning in higher education focusing on some of the factors driving increased online presence by the vast majority of colleges and universities in the U.S. (Allen \& Seaman, 2017; Gladhart, 2010; Lederman, 2018).

The Meso domain of research looks specifically at some of the key reasons higher education institutions have been dedicating resources and personnel to support learners with disabilities who take online courses (Center for Educational Innovation, n.d.; Loftus, 2019; Rothstein, 2010; Perez\& Ali, 2010). Laws and regulations related to campus accessibility, in general, and accessible online education, in particular, are examined (deMaine, 2017; Federal Communications Commission, 2017; Helland, 2017; Huss \& Eastep, 2016; U.S. General Services Administration, n.d.). Key activities and endeavors undertaken by higher education institutions in response to accessibility-related laws and regulations are appraised and discussed (Seale, 2014; Yuknis \& Bernstein, 2017). This domain also examines the organizational structure of higher education institutions to gauge its impact on responses and reactions by those institutions to accessibility-related laws and regulations (Cohen \& Kisker, 2010; deMaine, 2014; Higher Education Compliance Alliance, n.d.; Manning, 2013).

The Micro and the final domain of research focuses on designing accessible online courses and faculty training and development related to supporting learners with disabilities who take online courses (Barber \& King, 2016; Baumgartner, 2001; Holmes \& Kozlowski, 2015; Simoncelli \& Hinson, 2008). The Micro domain also examines current best practices to create, implement, and support effective, efficient, and accessible online learning courses. Further, the Micro domain assesses and determines how higher education institutions can take proactive measures to ensure that equitable access and support are afforded to learners with disabilities who take online courses (Basham, Stahl, Ortiz, Rice \& Smith, 2015; Burgstahler, 2015; Craig, Smith Frey, 2019; Gappa, Austin \& Trice, 2007; Rose, Meyer \& Hitchcock, 2011). Table 1 lists the three domains, subdomains, and the key authors and publications. 
Table 1

Literature Map

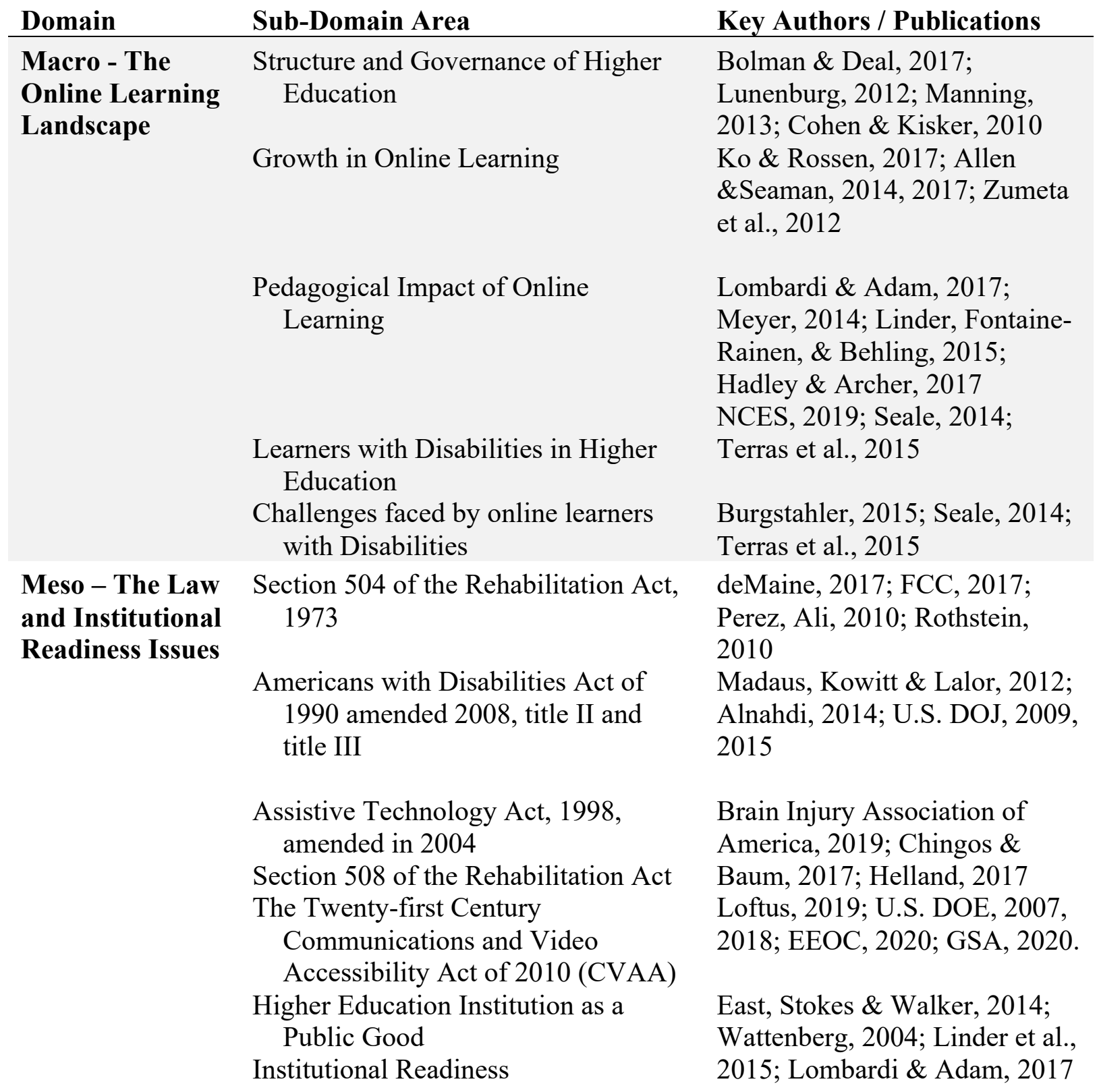




\begin{tabular}{|c|c|c|}
\hline $\begin{array}{l}\text { Micro - 1) } \\
\text { Designing } \\
\text { accessible online } \\
\text { courses; 2) } \\
\text { Faculty } \\
\text { Development }\end{array}$ & $\begin{array}{l}\text { Design } \\
\text { Online Learning Accessibility at the } \\
\text { Onset } \\
\text { Proactive Accessible Course Design } \\
\text { Techniques and Approaches } \\
\text { Universal Design for Learning } \\
\text { Web Content Accessibility Guidelines } \\
\text { Quality Assurance in Online } \\
\text { Education } \\
\text { Quality Matters } \\
\text { Faculty Development } \\
\text { Training and Pedagogy } \\
\text { Issues and Challenges } \\
\text { Time commitment } \\
\text { Workload balance } \\
\text { Incentives }\end{array}$ & $\begin{array}{l}\text { Burgstahler, 2003; 2015; } \\
\text { Coombs, 2010; QM, } 2018 \\
\quad \text { Rogers-Shaw, Carr- } \\
\text { Chellman \& Choi, 2017; } \\
\text { Hollingshead, 2017 } \\
\text { Web3c WAI, n.d.; } \\
\text { Betts et al., 2013; Cohn et al., } \\
\text { 2016; Coy et al., 2014; } \\
\text { deMaine, 2017; Diefenderfer, } \\
\text { 2019; Herman, } 2012\end{array}$ \\
\hline
\end{tabular}

\section{Learners with Disabilities and Online Education}

According to the Americans with Disabilities Act (ADA) of 1990, amended 2008, the term disability refers to an individual: (a) with a physical or mental impairment that substantially limits one or more major life activities of the individual; (b) who has a record of the impairment; or (c) as regarded as having such an impairment (U.S. Department of Justice, 2009). Major life activities involve limitations in caring for oneself, performing physical activities, seeing, hearing, speaking, learning, reading, and concentrating (National Center for Education Statistics, 2019). Students with disabilities taking online courses can have one or more impairments that affect their ability to have equal access. Section 504 of the Rehabilitation Act of 1973 is a federal law that protects the rights of individuals with disabilities from discrimination solely on the basis of the disability from programs that receive federal assistance.

The National Center for Education Statistics (2019) reports that psychological disabilities such as depression, anxiety, and post-traumatic stress can additionally pose significant barriers to learning for the student. Despite the many challenges, the enrollment numbers for students with disabilities at post-secondary institutions continue to rise (Patton et al., 2016). Online learning presents increased opportunities for students with disabilities to complete their post-secondary education, especially for students who are less inclined to navigate the on-campus landscape (Basham, Stahl, Ortiz, Rice \& Smith, 2015; Case \& Davidson, 2011).

Unfortunately, students with disabilities have a lower degree completion rate than their non-disabled peers (Izzo, Murray \& Novak, 2008; Katsiyannis, Zhang, Landmar, \& Reber, 2008).

While online learning offers many opportunities for access to higher learning, when courses do not take into consideration students with disabilities, this can create many challenges, concerns, and some uncertainties for the academy. According to Vasek (2005), faculty members at most institutions are not always prepared to provide the necessary accommodations to assist students with disabilities who take online courses. Seale (2014) argues that some faculty members 
believe that student support services such as disability offices are the sole entities that are responsible for making sure the student receives the appropriate accommodations.

As a result, at many institutions the Office of Accessibility is often seen as the main entity or sole entry point for students who need accommodations due to disabilities. Yet, many online courses are not designed to be adjusted in a post-hoc fashion to facilitate the complete integration of learners with disabilities. Thus, given the reactive approach to accommodate the needs of students with disabilities, faculty and staff are challenged when trying to retrofit the learning contents and assessments used in those courses to make them more accessible (Case \& Davidson, 2011). Alternatively, Burgstahler (2015) and Oswal and Meloncon (2014) advocate for designing online courses with accessibility at the onset; thus, taking a proactive approach.

The Universal Design for Learning (UDL) framework can facilitate proactive design and development of instruction thereby making online content accessible for a wider range of students with various abilities (Burgstahler, 2015; Tobin, 2014; Wynants \& Dennis, 2017). Research has found that faculty who implement UDL principles enhance the quality of the learning experiences for all learners by ensuring content is delivered through multiple modalities which provides multiple means to engage in learning, while also giving the learner opportunities to demonstrate their knowledge in multiple ways (Dell, Dell \& Blackwell, 2015; Hollingshead, 2017).

When courses are offered solely online, students with disabilities, like all students, find they must take online courses to progress in their programs of study. Given that students with disabilities are a diverse population, they are challenged in many ways in trying to navigate online courses that do not consider accessibility (Burgstahler, 2015; Gladhart, 2010; World Health Organization, 2011). In addition to the diversity of disability, these students also have demographic characteristics with differences in gender, age, socioeconomic status, sexuality, ethnicity, and culture. Therefore, supporting the student has to focus not only on the disability but on the whole person, as is the case in designing for non-disabled students.

\section{Legal Requirements Issues}

Academic institutions in the U.S. must determine ways to ensure compliance to the disability laws based on their understanding of the laws to ensure student needs are being addressed through their various internal offices such as accessibility, legal, risk management, and student support services, instructional design, and faculty professional development. While there have been several high-profile disability court cases (Helland, 2017; Loftus, 2019; U.S. Dept. of Education, Office of Civil Rights, 2014), few provide the precedent to assist higher education institutions on how to meet the legal requirements for designing accessible online courses (Helland, 2017; Loftus, 2019; Rothstein, 2010). However, there is enough information for higher education institutions to take proactive measures in the design and delivery of their online courses (Perez \& Ali, 2010; U.S. Department of Education [DOE], 2010; U.S. DOE, Office of Civil Rights [OCR], 2014).

There are several federal and state laws and statutes in place regarding individuals with disabilities. Table 2 includes laws and statutes that require equity in accommodation and offer protection against discrimination to those individuals and have an impact on Higher Education. 
Table 2

Assistive-Related Law Pertaining to Higher Education

\begin{tabular}{|c|c|c|c|}
\hline Law & Year & Focus & Impact \\
\hline $\begin{array}{l}\text { Americans with Disabilities } \\
\text { Act (ADA) }\end{array}$ & $\begin{array}{l}1990, \\
\text { amended } \\
2008\end{array}$ & $\begin{array}{l}\text { Anti-discrimination statute } \\
\text { designed to ensure equal } \\
\text { access }\end{array}$ & Direct \\
\hline $\begin{array}{l}\text { Sec } 504 \\
\text { of the Rehabilitation Act }\end{array}$ & 1973 & $\begin{array}{l}\text { Protects the rights of } \\
\text { individuals with disabilities } \\
\text { from discrimination solely on } \\
\text { the basis of the disability }\end{array}$ & Direct \\
\hline $\begin{array}{l}\text { Sec } 508 \\
\text { of the Rehabilitation Act }\end{array}$ & $\begin{array}{l}1998,2000, \\
\text { currently in } \\
\text { revision }\end{array}$ & $\begin{array}{l}\text { Promotes equality for people } \\
\text { with disabilities is responsible } \\
\text { for developing Information and } \\
\text { Communication Technology } \\
\text { (ICT) standards and guidelines }\end{array}$ & Indirect \\
\hline Higher Education Act (HEA) & $\begin{array}{l}1965, \\
\text { amended } \\
2008\end{array}$ & $\begin{array}{l}\text { Broaden access and improve } \\
\text { outcomes for students with } \\
\text { disabilities }\end{array}$ & Direct \\
\hline $\begin{array}{l}\text { Technology-Related } \\
\text { Assistance for Individuals } \\
\text { with Disabilities (TRAID) } \\
\text { Act }\end{array}$ & $\begin{array}{l}1988, \\
\text { amended } \\
1994\end{array}$ & $\begin{array}{l}\text { Access and Funding for } \\
\text { Assistive Technology }\end{array}$ & Direct \\
\hline $\begin{array}{l}21^{\text {st }} \text { Century Communications } \\
\text { and Video Accessibility Act } \\
\text { (CVAA) }\end{array}$ & 2010 & $\begin{array}{l}\text { Accessibility compliance for } \\
\text { the web and other technologies }\end{array}$ & Indirect \\
\hline Assistive Tech Act & $\begin{array}{l}1998, \\
\text { amended } \\
2004\end{array}$ & $\begin{array}{l}\text { Financing state activities and } \\
\text { programs for device } \\
\text { reutilization, device } \\
\text { demonstration and device } \\
\text { loans }\end{array}$ & Direct \\
\hline
\end{tabular}

Although higher education institutions must comply with the aforementioned laws and statutes, Betts et al. (2013) state that "accessibility is the right thing to do and training should be focused on students, their engagement online, and program completion" (p.52), and therefore, go beyond the need to comply with laws. In fact, the laws alone do not provide sufficient guidance to ensure compliance. This is because they do not explicitly specify online courses in higher education. The lack of specific mention of online education in these laws has presented some challenges for those involved in delivering content to students with disabilities because there are no clear guidelines or standards on exactly how accessibility compliance is to be accomplished.

\section{Faculty Development to Support Online Learners with Disabilities}

As teaching online requires designing and delivering instruction that is very different from how it is delivered in face-to-face settings, designing instruction that is considerate of the needs of 
students with disabilities adds complexity to the online environment. The key issue that remains to be resolved is how to best support faculty to gain the change in perspective and mind-set needed to have accessibility concepts at the onset when designing online instruction (Rogers-Shaw, CarrChellman, \& Choi, 2018). Many higher education faculty members are not often aware of the need to consider students with disabilities in the design of online learning courses (Burgstahler, 2015). This research argues that faculty need to undergo a challenge to their established perceptions or have a transformative experience that can serve as a catalyst for them to create inclusive, engaging and interactive online learning courses that are accessible for all students.

Burgstahler (2015) and McQuiggan (2012) propose that faculty would need this kind of experience to understand the online context of learning of their students and their broad range of abilities. Professional development provides tremendous opportunity to introduce proactive frameworks such as Quality Matters (QM) and Universal Design for Learning (UDL) in designing online courses (Craig, Smith \& Frey, 2019).

Therefore, given the need, professional development and training should help faculty position themselves in the context of their students with disabilities (National Center on Disability and Access to Education [NCDAE], n.d.). Incorporating UDL into professional development would assist faculty in designing equitable and inclusive experiences to promote learning for all students (Wynants \& Dennis, 2017).

To meet the challenges of time and scheduling conflicts, individualized, flexible, multimodal training should be offered to accommodate different teaching schedules and the ebb and flow in the seasonal cycles of a semester (Herman, 2012). Seale (2014) argues that faculty prefer training experiences that are less time-intensive and more portable. Because faculty have heavy teaching loads, faculty training should be in the form of just-in-time formats, as such an approach permits a quick refresher or answer to a specific question (NCDAE, n.d.). Support and training activities should be faculty-centered and customized to their specific learning needs and adapted to teaching discipline (Gappa, Austin \& Trice, 2007). To accommodate the differences in faculty schedules, online videos should be available to watch at convenient times.

\section{Purpose of this Study and Research Questions}

Academic progression of students with disabilities taking online courses through traditional higher education institutions is of significant concern as it relates to the high attrition rate among this population. Review of literature reveals that course content that is not accessible and usable to students with disabilities is a hindrance to their progress and retention. Research also reveals that faculty are often unaware of how to develop accessible online content (Huss \& Eastep, 2016; Schmidt, Tschida \& Hodge, 2016; Terras, Leggio \& Phillips, 2015; Wynants \& Dennis, 2018).

The research questions addressed by the study are:

1. What are faculty perceptions of their knowledge and practices in creating accessible online courses for students with disabilities?

2. How important do faculty think professional development supports are to help them incorporate accessibility considerations in their online courses?

3. Do faculty perceptions vary by key background factors for their capacity to design and implement accessible online tools for students with disabilities? 


\section{Methods}

\section{Research Design}

We followed a quantitative survey-based research approach with two open-ended questions. Because the objective of this study is to make inferences about faculty perceptions of their knowledge of laws, institutional policies, online pedagogical practices, and professional development support at a single point in time, a survey was the preferred method of data collection due to the potential for rapid turnaround and capacity for wide coverage and broad application.

\section{Survey Instrument}

The survey instrument for the study had three major content areas that are constructed to accommodate various faculty responses to items on the questionnaire. These are 1) Accessibility knowledge, 2) Accessibility Application/Practice, and 3) Accessibility Professional Development and have 66 fixed-choice items combined with two open-ended questions to provide additional insights. The survey requires responses to five-point Likert scales to measure faculty awareness and perception of their knowledge and practices in their online courses. The Likert-scale question for the subcategories address the level of awareness (24 items) for each item on a range: $1=$ Not at all aware, $2=$ Slightly aware, $3=$ Somewhat aware, $4=$ Moderately aware, and $5=$ Very aware. The Likert-scale question for the subcategories on practice (31 items) address the degree of use for each item on a range: $1=$ Never, $2=$ Rarely, $3=$ Sometimes, $4=$ Very often, and $5=$ Always. The Likert-scale question for the subcategory, Professional development (17 items), addresses the level of agreement for each item on a range: $1=$ Strongly Disagree, $2=$ Disagree, $3=$ Neither agree or disagree, 4= Agree, and 5= Strongly agree. A few of the items on the level of importance for each item on a range: $1=$ Not important, $2=$ Slightly important, 3= Moderately important, 4= Important, and $5=$ Very important. Open-ended questions at the end of the survey provided additional input from respondents regarding what support would be helpful to achieve accessible design in their courses.

After an initial draft of the survey was created, it was assessed for content validity by four expert reviewers in higher education including 1) Director of Disability Services, 2) Assistive Technology Specialist, 3) Instructional Designer at the Center for Teaching and Learning and 4) specialist in Quality Matters and Online Learning. In addition, the survey was piloted for usability and content accuracy with six online faculty representing the three institutions. These faculty provided feedback on various aspects of the instrument, which led to the inclusion of several questions regarding demographics and a wording change from accommodation to accessibility on online courses.

\section{Setting}

Three universities representing four-year public universities were invited to participate in this study. These three universities were chosen primarily by convenience. All three institutions are located in the southeastern region of the United States. The universities have different size enrollments, and due to their size and scope of activities, provide different experiences in offering distance courses and programs. All three are primarily residential with a significant undergraduate student population. The universities offer various courses, certificates, and degree programs online. An electronic survey was administered to the campuses through their distance education divisions to the faculty who teach online. 


\section{Participants}

A total of 182 faculty responded to the survey. The study had a $17 \%$ response rate. The respondents were mostly female $(n=103,56.6 \%)$, male $(n=67,36.8 \%)$, and those who preferred not to answer $(n=12,6.6 \%)$. Table 3 presents a description of the participants, including age, rank, primary online delivery method, level of teaching, years teaching, years teaching online, support received to teach online and funds used for training and development.

\section{Table 3}

Faculty Demographic Characteristics $(n=182)$

\begin{tabular}{|c|c|c|c|}
\hline Variables & Level & Frequency & Percentage \\
\hline \multirow[t]{7}{*}{ Faculty Status/Rank } & Professor & 32 & $18 \%$ \\
\hline & Associate Professor & 37 & $20 \%$ \\
\hline & Assistant Professor & 32 & $18 \%$ \\
\hline & Instructor & 23 & $13 \%$ \\
\hline & Adjunct & 28 & $15 \%$ \\
\hline & Clinical Faculty & 10 & $5.5 \%$ \\
\hline & Other & 17 & $9.3 \%$ \\
\hline \multirow[t]{4}{*}{ Age Range } & $21-30$ & 4 & $2.2 \%$ \\
\hline & $31-40$ & 36 & $20 \%$ \\
\hline & $41-50$ & 61 & $33.5 \%$ \\
\hline & $61+$ & 40 & $22.0 \%$ \\
\hline \multirow[t]{4}{*}{ Years Teaching Online } & $0-2$ & 37 & $20.3 \%$ \\
\hline & $3-5$ & 55 & $30.2 \%$ \\
\hline & $6-10$ & 41 & $22.5 \%$ \\
\hline & $11+$ & 42 & $23.1 \%$ \\
\hline \multirow{7}{*}{$\begin{array}{l}\text { Disabilities Accommodated } \\
\text { Online }\end{array}$} & Cognitive & 10 & $5.5 \%$ \\
\hline & Hearing & 7 & $3.8 \%$ \\
\hline & Mental Health & 14 & $7.7 \%$ \\
\hline & Physical & 7 & $3.8 \%$ \\
\hline & Vision & 9 & $4.9 \%$ \\
\hline & Multiple & 95 & $52.2 \%$ \\
\hline & None & 36 & $19.8 \%$ \\
\hline \multirow{2}{*}{$\begin{array}{l}\text { Number of Training in } \\
\text { Online Teaching }\end{array}$} & None & 69 & $37.9 \%$ \\
\hline & Some & 112 & $61.5 \%$ \\
\hline \multirow[t]{7}{*}{ Communications on Training } & None & 20 & $11.0 \%$ \\
\hline & $1-3$ & 54 & $29.7 \%$ \\
\hline & $4-7$ & 39 & $21.4 \%$ \\
\hline & $8-12$ & 27 & $14.0 \%$ \\
\hline & $13-17$ & 11 & $6.0 \%$ \\
\hline & $18-24$ & 4 & $2.2 \%$ \\
\hline & $25+$ & 19 & $10.4 \%$ \\
\hline
\end{tabular}




\section{Data Analysis}

In this survey-based research study, descriptive statistics (means and standard deviations) are reported at the category and subcategory levels. Cronbach's alpha was used to check the internal consistency of the responses to the survey items and was found to be .943 for all items. A 4 X 4 X 2 between-subjects factorial ANOVA was conducted for professional development of participants who are grouped in one of four age ranges and teaching online in one of four ranges by year, and who received some training for online teaching versus no training for online teaching. The qualitative data was open coded using content analysis as described by Creswell (2013). Themes were identified based on the patterns identified from the categories. Then, relationships between themes were consolidated and assigned a label based on findings that emerged.

\section{Results}

\section{Faculty Perception of Knowledge, Practice and Professional Development Supports for} Online Accessibility

Descriptive statistics (means and standard deviations) for each of the three categories knowledge, application/practice, and professional development and subcategories are reported in Table 4. The Knowledge category $(M=2.99)$ rated level of awareness of standards and law, institutional policy, design guidelines, terminology, and accessibility checking protocols of tools. The Accessibility Application and Practice category $(M=2.93)$ rated level of use and practices with Word and PDF documents, LMS, and audio and video. The Professional Development category $(M=3.74)$ rated faculty's perceptions on challenges to practice, importance of training on standards and policies, technologies, and knowledge of specific learner disabilities.

\section{Table 4}

Descriptive Statistics on Survey Responses by Item Composite Direct Variable Group

\begin{tabular}{|c|c|c|c|}
\hline & Description & M & SD \\
\hline \multicolumn{4}{|l|}{ Knowledge } \\
\hline & Accessibility Standards/Law & 2.43 & 1.04 \\
\hline & Institutional Policy & 3.93 & 0.91 \\
\hline & Design Guidelines & 2.70 & 1.29 \\
\hline & Terminology & 3.55 & 1.42 \\
\hline & Accessibility Checking Feature & 2.34 & .75 \\
\hline \multicolumn{4}{|c|}{ Application/Practice } \\
\hline & Application Practice/Online Tools & 3.36 & 1.42 \\
\hline & Application Practice/Word and PDF & 3.04 & 0.94 \\
\hline & Application Practice/LMS & 2.67 & 0.85 \\
\hline & Application Practice/audio and video & 2.70 & 1.04 \\
\hline \multicolumn{4}{|c|}{ Professional Development } \\
\hline & Challenges to Application/Practice & 3.70 & 0.82 \\
\hline & Institutional Technology/Support & 4.04 & 0.84 \\
\hline & Standards \& Policies & 3.55 & 1.03 \\
\hline & Learners with Disability Knowledge & 3.74 & 1.00 \\
\hline
\end{tabular}




\section{Faculty Perceptions and Key Background Factors}

A 4 (age) X 4 (years teaching online) X 2 (received training for online teaching or not) between-subjects factorial ANOVA was conducted comparing accessibility knowledge, application and practice, and professional development for participants who are grouped in one of four age ranges [21-40, 41-50, 51-60,61+] and teaching online in one of four-year ranges, and who received some training for online teaching versus no training for online teaching. Assumptions of the factorial ANOVA were met. The descriptive statistics based on key background factors is reported in Table 5.

\section{Table 5}

Faculty Perception Based on Background Factors

\begin{tabular}{|c|c|c|c|c|c|c|c|}
\hline \multirow{3}{*}{$\begin{array}{l}\text { Key } \\
\text { Variables } \\
\text { A ge ranoe }\end{array}$} & \multirow[t]{3}{*}{ Overall } & \multicolumn{2}{|c|}{ Knowledge } & \multicolumn{2}{|c|}{ Application } & \multicolumn{2}{|c|}{ Professional Dev } \\
\hline & & $M$ & $S D$ & $M$ & $S D$ & $M$ & $S D$ \\
\hline & & \\
\hline$* 21-40$ & 40 & 2.90 & 1.51 & 2.90 & 1.40 & 3.87 & 1.56 \\
\hline $41-50$ & 61 & 3.00 & 1.30 & 2.97 & 1.42 & 3.77 & 1.50 \\
\hline $51-61$ & 40 & 2.84 & 1.50 & 2.90 & 1.42 & 3.55 & 1.54 \\
\hline Over 61 & 35 & 3.22 & 1.64 & 2.93 & 1.40 & 3.66 & 1.70 \\
\hline \multicolumn{8}{|c|}{ Years teaching online } \\
\hline $0-2$ & 37 & 2.77 & 1.42 & 2.70 & 1.20 & 3.87 & 1.63 \\
\hline $3-5$ & 55 & 2.95 & 1.33 & 3.01 & 1.40 & 3.78 & 1.53 \\
\hline $6-10$ & 41 & 3.17 & 1.62 & 3.15 & 1.60 & 3.63 & 1.60 \\
\hline$>10$ & 42 & 2.98 & 1.50 & 2.80 & 1.34 & 3.60 & 1.56 \\
\hline \multicolumn{8}{|c|}{ Training for teaching online } \\
\hline None & 69 & 2.46 & 1.13 & 2.59 & 1.22 & 3.66 & 1.60 \\
\hline *Some & 112 & 3.34 & 1.60 & 3.14 & 1.45 & 3.77 & 1.60 \\
\hline
\end{tabular}

\section{Background Factors and Knowledge of Accessibility}

While the main effect for age was not significant $(\mathrm{p}>.05)$ and the main effect for a number of years teaching online was also not significant $(\mathrm{p}>.05)$, a significant main effect for training for online teaching received was found $(\mathrm{F}(1,107)=17.5, \mathrm{p}<.05)$. Instructors who received some training for online teaching did slightly better $(M=3.33)$ than those who had none $(M=2.45)$ in their responses on their knowledge of accessibility. The interactions were not significant:

\section{Background Factors and Accessibility Application and Practice}

The main effect for age was not significant $(p>.05)$. However, a significant main effect for number of years teaching online $(\mathrm{F}(3,99)=7.374, \mathrm{p}<.05)$ and for training received for online teaching $(\mathrm{F}(1,99)=27.751, \mathrm{p}<.05)$ was found. Those who had training had higher perception $(M$ $=3.14)$ than those who had no training for online teaching $(M=2.57)$. The interactions were not significant: Tukey Post hoc test was performed for examining difference in experience of online teaching. It was found that those who taught online for 6-10 years $(M=3.16), \mathrm{p}>.009$ had 
significantly higher perception on their responses for application and practice than those who taught two years or less $(M=2.66)$.

\section{Background Factors and Professional Development}

The main effect for age was not significant $(p>.05)$. The main effect for the number of years teaching online $(\mathrm{p}>.05)$ and for training received for online teaching or not, were also not significant $(\mathrm{p}>.05)$. The interactions were not significant.

\section{Accessible Design in Online Courses from Open-Ended Data}

A total of 85 faculty instructors provided additional feedback by responding to the openended question on the survey. The themes that resulted based on the patterns identified from the categories is reported in Table 6.

\section{Table 6}

Accessible Design in Online Courses $(n=85)$

\begin{tabular}{lll}
\hline Category & Frequency & Percentage \\
\hline Training Needed & & \\
Laws & 9 & 10.6 \\
Accessibility of tools (Word, LMS) & 9 & 10.6 \\
Student with disabilities & 8 & 9.4 \\
Standards (QM and other Standards) & 7 & 8.2 \\
\hline Type of Training & & \\
One-to-one support/Coaching & 9 & 10.6 \\
Need for flexibility & 8 & 9.4 \\
Need just-in-time & 5 & 5.9 \\
\hline Challenges to Accessible Design & & 16.5 \\
Too much time to design & 14 & 15.3 \\
Lack of time to attend training & 13 & 8.2 \\
Captioning/transcription services & 7 & 7.1 \\
Reactive approach to instruction & 6 & \\
\hline
\end{tabular}

Training. Faculty mentioned the need for training on disability laws $(n=9)$, standards $(n$ $=7)$, students with disabilities $(n=8)$, and accessibility features of tools $(n=9)$ to be beneficial in creating accessible design in their courses. For example, one faculty member wrote, "Canvas specific accessibility trainings are needed and periodic refreshers or professional development on the policies and standards." And another faculty member wrote "...More workshops on Autism and cognitively impaired. We have no idea on specific accessibility issues to assist these populations." Regarding tools, one faculty member wrote, "I had no idea there were already features built into the software I regularly use to make documents, PDFs, videos, etc."

Type of Training. Some faculty members reported a need for flexible training $(n=8)$ and just-in-time training $(\mathrm{n}=5)$ as important to consider. One faculty member stated, "The time to develop a course makes it so hard even before accessibility and accommodations are addressed, and as a faculty member, I would develop a much stronger course if I had assistance throughout the process." Another wrote, "Workshops or help chats online when I'm not able to physically 
attend a seminar or workshop" as helpful. Some faculty stated that support could come in the form of, "Ongoing workshops on QM standards and universal principles, and accessibility." Several faculty members state the need for coaching $(n=9)$ as a benefit. As one faculty member wrote, "It also would be helpful to have 'coaches' who could assist faculty in redesigning online courses to be more accessible." Another faculty member stated, "It would be helpful to have one-on-one consultations where someone with broad training could sit down with me to make my materials and LMS site more accessible."

Challenges to Accessible Design. Some faculty members perceived that it takes too much time to design courses $(n=14)$ and that they lack time for training $(n=13)$. Some faculty stated that they would consider a reactive approach $(n=6)$ to incorporating accessibility into their course design. One faculty member wrote that, "Given the limited time I have as an instructor, I have been reactive rather than proactive in addressing accessibility in my online courses, when I have a student that has a requirement." Also, faculty stated that captioning and transcription support services $(n=7)$ would be very helpful in alleviating some of the workload.

\section{Discussion}

The survey findings yielded important insights regarding faculty knowledge of laws and standards as well as their responsibility to accessibility practices and professional development support they find beneficial. The results of this study indicate that there is a need to promote education and access to information on disability and the faculty role in the accommodation of students online.

\section{Knowledge}

Faculty reported being very knowledgeable on various accessibility terms and in their legal responsibility in providing accommodations to students with disabilities. They also reported being very knowledgeable about their institution's legal obligation. However, faculty are much less aware of the laws and standards that formed the basis of institutional policies. For instance, faculty are moderately aware of the Americans with Disabilities Act of 1990. However, they were only slightly aware of Section 504 of the Rehabilitation Act of 1973. They are less aware of how these laws impact their design and delivery of online courses. This was also reinforced in the open-ended comments where faculty requested knowledge and training on laws and standards. Nonetheless, higher education institutions are legally bound to adhere to both laws which prohibit discrimination and guarantee equal access to all individuals with disabilities (United States Department of Education, 2018). Thus, higher education institutions must continue to take proactive steps to close the gap in faculty knowledge regarding how federal laws impact the design of online courses.

In addition, in the open-ended comment, faculty also requested training on the disabilities students have and tools that can be used to support students with disabilities. Early studies indicate links between faculty awareness and knowledge of disability laws and being disposed to accommodating the needs of students (Bowman \& Marzouk, 1990; Rao \& Garten, 2003). The implications are that lack of awareness and knowledge are impediments to faculty accessibility practices. This establishes the need for faculty education on disability laws, standards, needs of students, and accessibility of tools and applications. 


\section{Practice}

Findings reveal that faculty infrequently apply practices that facilitate accessibility. Their perceptions of the use of videos, Word and PDF documents were high, and perception of the use of Google Apps and audio in online courses was low. Faculty perception of their need to provide a statement on their respective syllabi regarding disability accommodations was also high. However, faculty perception of use was low in regard to providing transcripts and captions for video. In the open-ended survey responses, faculty reported that captioning the videos themselves was a very time- intensive process and that it would be beneficial to them for a specific department within the university to provide those services or even outsource that task to an external vendor. Yet, faculty frequently use videos in their courses as they serve as an alternative to text-only instruction. A key advantage of video-enhanced instruction is that it allows students to learn at their own pace and view material as often as needed. As Kay (2012) noted, the integration of videos in instruction helps enhance students' engagement with course materials. Also, videos are beneficial to those with cognitive challenges and different learning styles (Linder, 2016).

Nonetheless, research shows that a reactive approach to course design can cost more and requires more time than a proactive approach to course design (deMaine, 2014). This is because with a reactive design, key sections of the course often need to be altered and adjusted to meet the new user needs and requirements and this takes additional time and effort from the faculty and other support staff of the university. With proactive design, potential changes are anticipated and thus embedded in the initial course development process. Furthermore, as it is already a common practice for faculty to include a statement on the syllabus regarding accessibility, this studentfaculty relationship and commitment to inclusiveness is only a first step in a move beyond a legal obligation.

\section{Professional Development}

Participants reported that professional development on accessibility is very important. The data collected show that faculty perception was high for support using technology to teach students with disabilities and the need for assistance from internal units and resources like the Office of Online Programs, Center for Teaching and Learning, Instructional Designer, etc. in adapting their online courses. Further, when faculty were asked about their knowledge in developing accessible online courses, they reported a high perception for support in training and knowledge on how to improve accessibility application and practices, and on overcoming the challenges to meeting the time commitment involved in designing online content.

Faculty also rated the need for support in video captioning and training on the policies and procedures for students with disabilities as very important. Faculty rated the need for training on using WCAG Guidelines and Section 508 of the Rehabilitation Act regarding technology use as moderately important. From the open-ended responses, faculty preferred periodic refreshers, as well as professional development on policies and standards. They also specifically requested workshops on autism and cognitive impairments. Research also supports that students with disabilities find few of the faculty who are familiar with their disability and need for accommodations (Stevens, Schneider \& Bederman-Miller, 2018; Terras, Leggio \& Phillips, 2015).

Due to the nature of faculty work and the diversity of needs and teaching schedules, faculty have limited time to attend traditional workshops that require they attend at a specific time and location (Gappa, Austin \& Trice, 2007; Lombardi \& Adam, 2017). Some faculty reported an alternative training program could be beneficial. They requested online workshops, one-to-one 
workshops, coaching, and flexibility in scheduling workshops based on their schedule. When professional development on accessibility is offered, it is important to keep these types of training in mind. In addition, faculty reported challenges to negotiating their time with professional and disciplinary criteria of tenure and promotion, which rewards scholarly productivity ahead of teaching and other activities such as student advising and community involvement. Faculty have challenging teaching loads and are expected to integrate new technologies when designing and developing learning experiences for their students.

Challenges to Designing Accessible Courses. There were four themes that emerged as challenges which include, designing accessible courses takes too much time, lack of time to attend training, captioning/transcription services are not provided by universities, and faculty use a reactive approach to instruction instead of being proactive. Given these challenges, it is important for administrators to provide the support that faculty need in terms of time, also training opportunities, and captioning/transitioning services. Quality assurance certification programs such as Quality Matters include accessibility as an essential standard that requires the faculty to be more proactive than reactive.

\section{Key Background Factors}

Statistically significant differences were noted with respect to perceptions of knowledge and practices with accessibility in online courses. Results revealed faculty with online teaching experience between 6-10 years performed slightly better with practice than those who had been teaching two years or less. Research on expertise explains how experience and practice allow people to excel in domain-related tasks. Therefore, the difference in practice with regards to accessibility in online courses between the two groups appears to be linked to expertise. It can be expected that the scores of the participants who fall in the novice category (i.e., 2 years or less experience teaching online), will most likely improve as they teach longer and thus achieve expertlevel performance in the field.

Results also showed that faculty who received professional development training in online learning had a very significant influence on accessibility knowledge and practice than those who had not received any training. These findings are comparable to Wynants and Dennis' (2017) findings that training improves faculty accessibility knowledge and practice in online courses. Although faculty perceptions regarding professional development were very important, $37 \%$ of survey participants reported that they had not received any training for online teaching in the past year.

\section{Limitations}

There were some methodological limitations with the study. First, the response rate of the survey was only $17 \%$. Also, 182 faculty members from three institutions participated in the survey, $51 \%$ of the responses came from one institution. Second, all the data collected were self-reported. This could result in a response bias. Third, the domain of faculty expertise was not a factor that was examined in the study. Fourth, the data collected did not convey the types and level of training faculty receive at their institutions. Consequently, the reader may interpret the results of the study with caution because they may have limited generalizability in different contexts and settings.

\section{Recommendations for Future Research}

Areas for future research may include an examination of the impact faculty background has on their knowledge and competency regarding supporting learners with disabilities who take 
online courses. The availability, type, and scope of resources and activities related to faculty training, e.g., Center of Teaching of Learning, Online Education Office, and financial allocation, may be explored to determine their impact on faculty knowledge and practice. Future research may likewise explore the connection between faculty's background and experience with disabilityrelated issues and their academic practice. It will also be worthwhile to examine the perspective of faculty without prior experience teaching online or teaching only in hybrid formats on accessibility issues related to learners with disabilities.

\section{Implications and Conclusion}

Many students with disabilities are now taking online courses to fulfill their degree program requirements. Consequently, higher education institutions, no matter their size or enrollment level, must take the appropriate steps to ensure that their online courses are legally compliant with all disability-related laws, rules, and ordinances. As the results of this study show, higher education institutions must make greater efforts to ensure that their faculty members are adequately trained and supported to teach effectively and efficiently in the online learning environment. Moreover, higher education institutions must ensure that their level of investments in both academic tools and personnel resources are in congruence with their focus on increasing their online offerings.

It is recommended that accessibility training provided by higher education institutions includes a focus on disability-related laws and specific disabilities and designing instruction with accessibility in mind. Institutions should also emphasize proactive strategies for online course design in their training. This is to avoid having to retrofit online courses to meet legal requirements and the educational needs of learners with disabilities. As important, professional development support needs also to incorporate a transformational learning framework that scaffolds critical reflection and reflective discourse. Such an approach will help provoke reflection on beliefs and practices regarding inclusive teaching approaches in online courses for all students, including those with disabilities. 


\section{References}

Allen, I. E. \& Seaman, J. (2014). Grade change: Tracking online education in the United States. https://www.onlinelearningsurvey.com/reports/gradechange.pdf

Allen, I. E. \& Seaman, J. (2017). Digital learning compass: Distance education enrollment. https://onlinelearningsurvey.com/reports/digtiallearningcompassenrollment2017.pdf

Alnahdi, G. (2014). Assistive technology in special education and the universal design for learning. Turkish Online Journal of Educational Technology 13(2), 18-23.

Austin, A. E., \& Sorcinelli, M. D. (2013). The future of faculty development: Where are we going? New Directions for Teaching and Learning (133), 85-97.

Basham, J.D., Stahl, S., Ortiz, K., Rice, M.F., \& Smith, S. (2015). Equity matters: Digital \& online learning for students with disabilities. Lawrence, KS: Center on Online Learning and Students with Disabilities.

Betts, K., Cohen, A., \& Broadus, C. (2013). Strategies to increase online student success for students with disabilities. Journal of Asynchronous Learning Networks, 17(3), 49-64.

Brain Injury Association of America. (2019). Assistive technology acts. Retrieved from https://www.biausa.org/public-affairs/public-policy/assistive-technology-act

Brooks, C. F. (2010) Toward 'hybridised' faculty development for the twenty-first century: Blending online communities of practice and face-to-face meetings in instructional and professional support programmes. Innovations in Education and Teaching International, 47:3, 261-270.

Bolman, L. G., \& Deal, T. E. (2000). Reframing organizations: Artistry, choice, and leadership. National Association of Secondary School Principals. NASSP Bulletin, 84(612), 88 .

Bowman, O. J. \& Marzouk, D. K. (1990). Using the Americans with Disabilities Act of 1990 to empower university students with disabilities. American Journal of Occupational Therapy, 46, 450-456.

Burgstahler, S. (2003). Accommodating students with disabilities: Professional development needs of faculty. To Improve the Academy, 21(1), 179-195.

Burgstahler, S. (2015). Opening doors or slamming them shut? Online learning practices and students with disabilities. Social Inclusion, 3(6), 69-79.

CAST. (2019, January 29). UDL in Public Policy. http://www.cast.org/work-with-us/udl-publicpolicy.html\#.XGokepNKhZ0 
Chapko, N. (2017). Faculty Voices: Barriers to Implementing UDL Strategies. In P. Resta \& S. Smith (Eds.), Proceedings of Society for Information Technology \& Teacher Education International Conference (pp. 2516-2520). Austin, TX, United States: Association for the Advancement of Computing in Education (AACE). https://www.learntechlib.org/primary/p/177559/.

Chingos, M., \& Baum, S. (2017). The federal-states higher education partnership: how state manage their roles (pp. 1-18). https://www.urban.org/sites/default/files/publication/90306/2017.4.26_how_states_manage_t heir_roles_finalized_4.pdf

Cohen, A. M., \& Kisker, C. B. (2010). The shaping of American higher education: Emergence and growth of the contemporary system (2nd ed.). San Francisco: Jossey-Bass.

Cohn, J., Stewart, M. K., Theisen, C. H., \& Comins, D. (2016). Creating online community: A response to the needs of 21 st century faculty development. The Journal of Faculty Development, 30(2), 47-57.

Coombs, N. (2010). Making online teaching accessible: Inclusive course design for students with disabilities. San Francisco, CA: Jossey-Bass.

Coy, K., Marino, M., \& Serianni, B. (2014). Using universal design for learning in synchronous online instruction. Journal of Special Education Technology, 29(1), 63-74.

Craig, S. L., Smith, S. J. \& Frey, B. B. (2019) Professional development with universal design for learning: supporting teachers as learners to increase the implementation of UDL, Professional Development in Education, DOI: 10.1080/19415257.2019.1685563

Creswell, J. W. (2013). Qualitative inquiry \& research design: Choosing among five approaches (3rd ed.). Thousand Oaks, CA: SAGE.

Dell, C., Dell, T., \& Blackwell, T. (2015). Applying universal design for learning in online courses: pedagogical and practical considerations. Journal of Educators Online, 12(2), 166-192.

deMaine, S. D. (2017, July 26). From disability to usability in online instruction. Law Library Journal, 106, 531

Diefenderfer, A. B. (2019). Faculty Development in the Age of Evidence: Current Practices, Future Imperatives by Andrea L. Beach et al. The Review of Higher Education, 42(2), E-1.

East, L., Stokes, R., \& Walker, M. (2014). Universities, the public good and professional education in the UK, Studies in Higher Education, 39(9), 1617-1633.

Equal Employment Opportunity Commission (EEOC). (2020). U.S. Equal Employment Opportunity Commission. https://www.eeoc.gov/ 
Federal Communications Commission (FCC). (2017). 21st century communications and video accessibility act (CVAA). https://www.fcc.gov/consumers/guides/21st-centurycommunications-and-video-accessibility-act-cvaa

Gappa, J.M., Austin, A.E., \& Trice, A.G. (2007). Rethinking faculty work: Higher education's strategic imperative. New York, NY: Nolan Wiley \& Sons, Inc.

Gladhart, M. A. (2010). Determining faculty needs for delivering accessible electronically delivered instruction in higher education. Journal of Postsecondary Education and Disability, 22(3), 185-196.

Guilbaud, T. C. (2019). Faculty perception of knowledge and practice in designing and implementing accessible online courses (Publication No. 27547307.) [Doctoral dissertation, The University of North Carolina at Charlotte]. ProQuest Dissertations \& Theses.

Hadley, W., \& Archer D.E. (2017). College students with learning disabilities: An at-risk population absent from the conversation of diversity. In E. Kim, \& K.C. Aquino (Eds.), Disability as Diversity in Higher Education: Policies and Practices to Enhance Student Success (pp. 107-121). New York, NY: Routledge.

Helland, S. E. (2017, September 26). Class action plaintiff targets universities and colleges for website accessibility claims: Fordham and three others sued in one week [Web log post]. https://www.fredlaw.com/news_media/2017/09/26/1640/class_action_plaintiff_targets_univ ersities_and_colleges_for_website_accessibility_claims_fordham_and_three_others_sued_in _one_week

Herman, J.H. (2012). Faculty development programs: The frequency and variety of professional development programs available to online instructors. Journal of Asynchronous Learning Networks, 16(5), 87-106.

Hollingshead, A. (2017). Designing engaging online environment: Universal design for learning principles. In Milheim, K. L. (Ed.), Cultivating diverse online classrooms through effective instructional design (Chap. 14). Hershey, PA: IGI Global.

Huss, J. A., \& Eastep, S. (2016). Okay, our courses are online, but are they ADA compliant? An investigation of faculty awareness of accessibility at a midwestern university. i.e.: inquiry in education, (8)2, Article 2. http://digitalcommons.nl.edu/ie/vol8/iss2/2.

Izzo, M. V., Murray, A., \& Novak, J. (2008). The faculty perspective on universal design for learning. Journal of Postsecondary Education \& Disability, 21(2), 60-72.

Katsiyannis, A., Zhang, D., Landmark, L., \& Reber, A. (2008). Postsecondary education for individuals with disabilities: legal and practice considerations. Journal of Disability Policy Studies, 20(1), 35-45.

Kay, R. H. (2012), 'Exploring the use of video podcasts in education: A comprehensive review of the literature', Computers in Human Behavior 28(3), 820-831. 
Keengwe, J., \& Kidd, T. (2010, June). Towards best practices in online learning and teaching in higher education. http://jolt.merlot.org/vol6no2/keengwe_0610.htm

Ko, S., \& Rossen, S. (2017). Teaching online: A practical guide (4th ed.). New York: Routledge.

Kuhlenschmidt, S. (2010). Issues in technology and faculty development. In K. H. Gillespie, \& D.L. Robertson (Eds.), A Guide to Faculty Development (pp. 259-274). San Francisco: JosseyBass.

Lederman, D. (2018, November 7). Online education ascends. https://www.insidehighered.com/digital-learning/article/2018/11/07/new-data-onlineenrollments-grow-and-share-overall-enrollment

Linder, K. (2016). Implementation of and solutions for closed captioning in U.S. institutions of higher education: Results from a national study (Report 2016). Corvallis, OR: Oregon State University Ecampus Research.

Linder, K. E., Fontaine-Rainen, D. L., \& Behling, K. (2015). Whose job is it? Key challenges and future directions for online accessibility in US Institutions of Higher Education. Open Learning: The Journal of Open, Distance and e-Learning, 30(1), 21-34.

Loftus, P. (2019, January 05). District court: Harvard/MIT captioning lawsuit going forward. https://www.3playmedia.com/2016/11/08/mass-district-court-decision-harvardmit-lawsuitwill-go-forward/

Lombardi, A. R., \& Lalor, A. R. (2017). Faculty and administrator knowledge and attitudes regarding disability. Disability as diversity in higher education, 107-121.

Lunenburg, F. C. (2012). Organizational structure: Mintzberg's framework. International Journal of Scholarly, Academic, Intellectual Diversity, 14(1), 1-8.

Madaus, J., Kowitt, J., \& Lalor, A. (2012). The higher education opportunity act: Impact on students with disabilities. Rehabilitation Research, Policy, and Education, 26(1), 33-41.

Manning, K. (2013). Organizational theory in higher education. New York: Routledge.

Marchetti, C. (2011). The importance of interaction for academic success in online courses with hearing, deaf, and hard-of-hearing students, The International Review of Research in Open and Distributed Learning, 12(6), 1-19.

McQuiggan, C. (2012). Faculty Development for Online Teaching as a Catalyst for Change. Journal of Asynchronous Learning Networks, 16(2), 27-61.

Meyer, K. A. (2014). An analysis of the research on faculty development for online teaching and identification of new directions. Journal of Asynchronous Learning Networks, 17(4), 93-112.

National Center for Education Statistics (NCES). (2019). The NCES fast facts tool provides quick answers to many education questions (National Center for Education Statistics). https://nces.ed.gov/fastfacts/display.asp?id=60 
National Center on Disability and Access to Education (NCDAE). (n.d.). Providing training for faculty and staff: An essential element for your campus. http://ncdae.org/resources/tips/training.php

Oswal, S. K., \& Meloncon, L. (2014). Paying attention to accessibility when designing online courses in technical and professional communication. Journal of Business and Technical Communication, 28(3), 271-300.

Patton, L. D., Renn, K. A., Guido-DiBrito, F., \& Quaye, S. J. (2016). Student development in college theory, research, and practice. San Francisco, CA: Jossey-Bass.

Perez, T. E., \& Ali, R. (2010, June 29). U.S. Department of Education. Joint - Dear colleague letter: Electronic book readers. https://www2.ed.gov/about/offices/list/ocr/letters/colleague20100629.html.

Quality Matters (QM). (2018). Accessibility policy creation guidelines. https://www.qualitymatters.org/research

Rodesiler, C., \& McGuire, J. (2015). Ideas in practice: Professional development to promote universal design for instruction. Journal of Developmental Education, 38(2), 24-31.

Roehrs, C., Wang, L., \& Kendrick, D. (2013). Preparing faculty to use the quality matters model for course improvement. MERLOT Journal of Online Learning and Teaching, 9(1), 52-67.

Rogers-Shaw, C., Carr-Chellman, D. J., \& Choi, J. (2018). Universal design for learning: Guidelines for accessible online instruction. Adult Learning, 29(1), 2031. https://doi.org/10.1177/1045159517735530

Rose, D. H., Meyer, A., \& Hitchcock, C. (2011). The universally designed classroom: Accessible curriculum and digital technologies. Cambridge, MA: Harvard Education Press.

Rothstein, L. (2010, August 06). Higher education and disability discrimination: A fifty-year retrospective. https://papers.ssrn.com/sol3/papers.cfm?abstract_id=1653466

Schmidt, S.W., Tschida, C.M. \& Hodge, E.M. (2016). How faculty learn to teach online: What administrators need to know. Online Journal of Distance Learning Administration, 19(1). http://www.westga.edu/ distance/ojdla/spring191/schmidt_tschida_ho dge191.html

Seale, J. K. (2014). E-learning and disability in higher education accessibility research and practice. New York, New York: Routledge

Simoncelli, A., \& Hinson, J. M. (2008). College students with learning disabilities personal reactions to online learning. Journal of College Reading and Learning, 38(2), 49-62.

Stevens, C. M., Schneider, E., \& Bederman-Miller, P. (2018). Identifying faculty perceptions of awareness and preparedness relating to ADA compliance at a small, private college in NE PA. American Journal of Business Education (AJBE), 11(2), 27-40. 
Terosky, A. L., \& Heasley, C. (2014). Supporting online faculty through a sense of community and collegiality. Online Learning, 19(3), 147-161.

Terras, K., Leggio, J., \& Phillips, A. (2015). Disability accommodations in online courses: The graduate student experience. Journal of Postsecondary Education \& Disability, 28(3), 329340.

Tobin, T. (2014). Increase online student retention with universal design for learning. Quarterly Review of Distance Education, 15(3), 13-24.

U.S. Department of Education. (2018). Protecting Students with Disabilities. https://www2.ed.gov/about/offices/list/ocr/504faq.html

U.S. Department of Education, Office for Civil Rights (OCR), (2014). University of Montana Resolution Agreement (PDF).

http://www.umt.edu/accessibility/docs/AgreementResolution_March_7_2014.pdf

U.S. General Services Administration (GSA). (n.d.). IT accessibility laws and policies. https://www.section508.gov/manage/laws-and-policies

U.S. Department of Justice. (2009, July). A guide to disability rights law. https://www.ada.gov/cguide.htm

Vasek, D. (2005). Assessing the knowledge base of faculty at a private, four-year institution. College Student Journal, 39(2), 307-315.

Wattenberg, T. (2004). Beyond legal compliance: Communities of advocacy that support accessible online learning. The Internet and Higher Education, 7(2), 123-139.

Web3c WAI. (n.d.) Web content accessibility guidelines (WCAG) overview. https://www.w3.org/WAI/standards-guidelines/wcag/IT Accessibility Laws and PoliciesWorld Health Organization. (2011). World report on disability (Report 2011). Malta: WHO Library Cataloguing-in-Publication Data.

Wright, G. (2011). Student-centered learning in higher education. International Journal of Teaching and Learning in Higher Education, 23(1), 92-97.

Wynants, S. A., \& Dennis, J. M. (2017). Embracing diversity and accessibility: A mixed methods study of the impact of an online disability awareness program. Journal of Postsecondary Education \& Disability, 30(1), 33-48.

Yuknis, C., \& Bernstein, E. R. (2017). Supporting students with non-disclosed disabilities: A collective and humanizing approach. In E. Kim, \& K.C. Aquino (Eds.), Disability As Diversity In Higher Education: Policies and Practices to Enhance Student Success (pp. 318). New York, NY: Routledge

Zumeta, W., Breneman, D. W., Callan, P. M., \& Finney, J. E. (2012) Financing American higher education in the era of globalization. Cambridge, MA: Harvard Education Press. 


\section{Appendix A \\ Online Accessibility Faculty Questionnaire}

\section{Accessibility Knowledge}

\begin{tabular}{|c|c|c|c|c|c|}
\hline $\begin{array}{l}\text { What is your level of awareness } \\
\text { with the following? }\end{array}$ & $\begin{array}{l}\text { Not at } \\
\text { all } \\
\text { aware }\end{array}$ & $\begin{array}{l}\text { Slightly } \\
\text { aware }\end{array}$ & $\begin{array}{l}\text { Somewhat } \\
\text { aware }\end{array}$ & $\begin{array}{l}\text { Moderatel } \\
\text { y } \\
\text { aware }\end{array}$ & $\begin{array}{l}\text { Very } \\
\text { aware }\end{array}$ \\
\hline \multicolumn{6}{|c|}{ Accessibility Standards - Law } \\
\hline \multicolumn{6}{|c|}{$\begin{array}{l}\text { a. Section } 504 \text { of the Rehabilitation } \\
\text { Act of } 1973\end{array}$} \\
\hline \multicolumn{6}{|l|}{$\begin{array}{l}\text { b. Section } 508 \text { of the Rehabilitation } \\
\text { Act, updated } 2017\end{array}$} \\
\hline \multicolumn{6}{|l|}{$\begin{array}{l}\text { c. Americans with Disabilities Act } \\
\text { of } 1990 \text { and amendments of } 2008\end{array}$} \\
\hline \multicolumn{6}{|l|}{ d. Assistive Technology Act of 1998} \\
\hline \multicolumn{6}{|l|}{$\begin{array}{l}\text { e. Higher Education Opportunity } \\
\text { Act } 2008\end{array}$} \\
\hline \multicolumn{6}{|c|}{ Institutional Policy } \\
\hline \multicolumn{6}{|l|}{$\begin{array}{l}\text { f. How aware are you with your } \\
\text { institution's legal obligation in } \\
\text { providing accommodations to } \\
\text { students with disabilities? }\end{array}$} \\
\hline \multicolumn{6}{|l|}{$\begin{array}{l}\text { g. How aware are you with your } \\
\text { responsibilities as a faculty } \\
\text { member for providing Section } \\
\text { 504/ADA accommodations for } \\
\text { students with disabilities at your } \\
\text { institution? } \\
\end{array}$} \\
\hline \multicolumn{6}{|l|}{$\begin{array}{l}\text { h. How aware are you with your } \\
\text { institution's administration } \\
\text { process of providing instructional } \\
\text { accommodations to students with } \\
\text { disabilities? }\end{array}$} \\
\hline \multicolumn{6}{|l|}{$\begin{array}{l}\text { How aware are you with the } \\
\text { process that students undergo to } \\
\text { document their disability(ies) at } \\
\text { your institution? }\end{array}$} \\
\hline $\begin{array}{l}\text { How aware are you with your } \\
\text { institution's policy regarding the } \\
\text { students' option to self-disclose } \\
\text { their disability to Student } \\
\text { Disability Services to receive } \\
\text { accommodations? }\end{array}$ & & & & & \\
\hline
\end{tabular}




\begin{tabular}{|c|c|c|c|c|c|}
\hline $\begin{array}{l}\text { How aware are you with the } \\
\text { following Design Guidelines? }\end{array}$ & $\begin{array}{l}\text { Not at } \\
\text { all } \\
\text { aware }\end{array}$ & $\begin{array}{l}\text { Slightly } \\
\text { aware }\end{array}$ & $\begin{array}{l}\text { Somewhat } \\
\text { aware }\end{array}$ & $\begin{array}{l}\text { Moderate } \\
\text { ly } \\
\text { aware }\end{array}$ & $\begin{array}{l}\text { Very } \\
\text { aware }\end{array}$ \\
\hline \multicolumn{6}{|c|}{ Design Guidelines } \\
\hline \multicolumn{6}{|l|}{$\begin{array}{l}\text { 1. Quality Matters }(\mathrm{QM}) \\
\text { neral Standard 8: Accessibility and } \\
\text { Usability }\end{array}$} \\
\hline \multicolumn{6}{|l|}{$\begin{array}{l}\text { 2. Web Content Accessibility } \\
\text { Guidelines (WCAG 2.0) }\end{array}$} \\
\hline \multicolumn{6}{|l|}{$\begin{array}{l}\text { 3. Universal Design for Learning } \\
\text { (UDL) }\end{array}$} \\
\hline \multicolumn{6}{|l|}{ 4. Other standards } \\
\hline $\begin{array}{l}\text { How aware are you with the meaning } \\
\text { of following the terms as defined by } \\
\text { the ADA? }\end{array}$ & $\begin{array}{l}\text { Not at } \\
\text { all } \\
\text { aware }\end{array}$ & $\begin{array}{l}\text { Slightly } \\
\text { aware }\end{array}$ & $\begin{array}{l}\text { Somewhat } \\
\text { aware }\end{array}$ & $\begin{array}{l}\text { Moderate } \\
\text { ly } \\
\text { aware }\end{array}$ & $\begin{array}{l}\text { Very } \\
\text { aware }\end{array}$ \\
\hline \multicolumn{6}{|c|}{ Terminology } \\
\hline \multirow{2}{*}{\multicolumn{6}{|c|}{$\begin{array}{l}\text { 1. Accessible Technology } \\
\text { 2. Assistive Technology }\end{array}$}} \\
\hline & & & & & \\
\hline \multicolumn{6}{|l|}{ 3. Disability } \\
\hline \multicolumn{6}{|l|}{ 4. Reasonable Accommodation } \\
\hline \multicolumn{6}{|l|}{ 5. Reasonable Modification } \\
\hline \multicolumn{6}{|l|}{ 6. Usability } \\
\hline \multicolumn{6}{|l|}{ 7. Universal Design } \\
\hline \multirow{2}{*}{\multicolumn{6}{|c|}{ 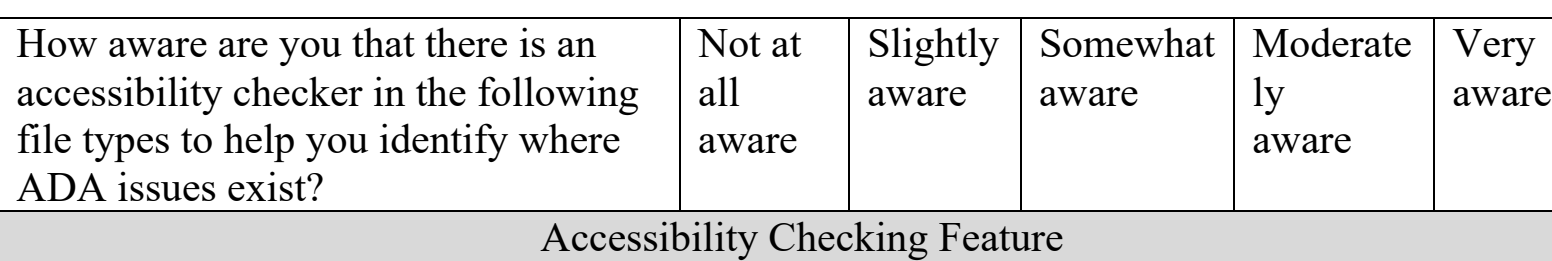 }} \\
\hline & & & & & \\
\hline \multicolumn{6}{|l|}{ 8. MS Word } \\
\hline \multicolumn{6}{|l|}{ 9. Adobe Acrobat Pro PDF } \\
\hline \multicolumn{6}{|l|}{$\begin{array}{l}\text { 10. LMS (Blackboard, Canvas, } \\
\text { Moodle) }\end{array}$} \\
\hline $\begin{array}{l}\text { 11. Google Apps (Doc., Sheets, } \\
\text { Forms) }\end{array}$ & & & & & \\
\hline
\end{tabular}

\section{Accessibility Application/Practice}

\begin{tabular}{|c|c|c|c|c|c|}
\hline $\begin{array}{l}\text { How often do you use the } \\
\text { following in your online courses? }\end{array}$ & Never & Rarely & Sometimes & Very Often & Always \\
\hline \multicolumn{6}{|c|}{ Application/Practice- Online Tools } \\
\hline a. Word documents & & & & & \\
\hline b. PDF documents & & & & & \\
\hline $\begin{array}{l}\text { c. Videos (YouTube, Vimeo, } \\
\text { Screencasts, etc.) }\end{array}$ & & & & & \\
\hline
\end{tabular}




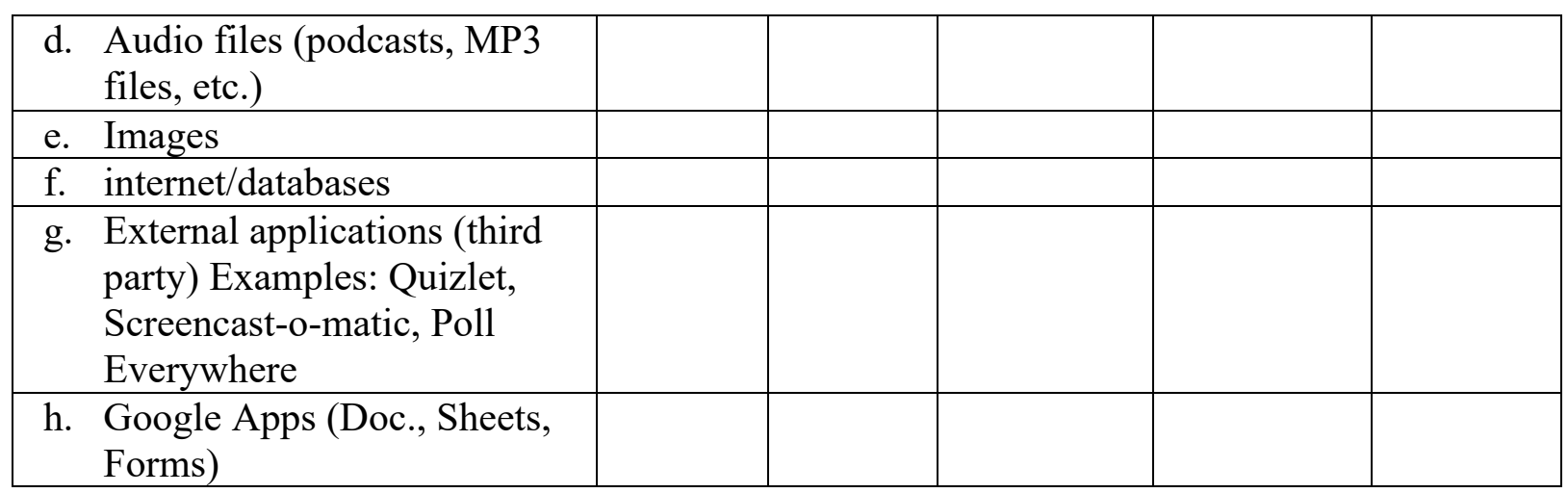

\begin{tabular}{|l|l|l|l|l|l|}
\hline $\begin{array}{l}\text { In your use of Word and PDF } \\
\text { documents, how often do you use } \\
\text { the following features? }\end{array}$ & Never & Rarely & Sometimes & Very Often & Always \\
\hline & Accessibility Practice - Word and PDF & \\
\hline $\begin{array}{l}\text { i. Use accessibility checker to } \\
\text { identify accessibility issues }\end{array}$ & & & & & \\
\hline $\begin{array}{l}\text { j. Apply Alternative Texts (alt } \\
\text { tags) to images in the } \\
\text { documents. }\end{array}$ & & & & & \\
\hline $\begin{array}{l}\text { k. Use numbers/bullets to } \\
\text { signify a list }\end{array}$ & & & & & \\
\hline $\begin{array}{l}\text { 1. Use an identified "header } \\
\text { style" to organize content }\end{array}$ & & & & & \\
\hline $\begin{array}{l}\text { m. Use an identified "header row } \\
\text { and header column" to } \\
\text { identify tables }\end{array}$ & & & & & \\
\hline $\begin{array}{l}\text { n. Use hyperlinks in text for } \\
\text { navigation purposes }\end{array}$ & & & & & \\
\hline
\end{tabular}

\begin{tabular}{|l|l|l|l|l|l|}
\hline $\begin{array}{l}\text { In using your institution's LMS } \\
\text { (Blackboard, Canvas, Moodle, } \\
\text { etc.), do you apply the following? }\end{array}$ & Never & Rarely & Sometimes & Very Often & Always \\
\hline $\begin{array}{l}\text { o. Use accessibility checker to } \\
\text { identify accessibility issues }\end{array}$ & Accessibility Practice - LMS & & \\
\hline $\begin{array}{c}\text { p. Add Alternative Text (alt tags) } \\
\text { to images }\end{array}$ & & & & & \\
\hline $\begin{array}{l}\text { q. Upload documents to correct } \\
\text { category (example: syllabus to } \\
\text { syllabus category) }\end{array}$ & & & & & \\
\hline r. Quiz & & & & & \\
\hline s. Synchronous Chat & & & & & \\
\hline
\end{tabular}




\begin{tabular}{|l|l|l|l|l|l|}
\hline $\begin{array}{l}\text { How often do you provide the } \\
\text { following in your online courses } \\
\text { for the audio/video you use? }\end{array}$ & Never & Rarely & Sometimes & Very Often & $\begin{array}{l}\text { Alway } \\
\text { s }\end{array}$ \\
\hline & \multicolumn{2}{|l|}{ Accessibility Practice - Audio/Video } & \\
\hline $\begin{array}{l}\text { t.Transcripts with audios } \\
\text { (podcasts, MP3, AudioBoom, } \\
\text { etc.) }\end{array}$ & & & & & \\
\hline $\begin{array}{l}\text { u.Transcripts with videos } \\
\text { (YouTube, Vimeo, Screencasts, } \\
\text { Kaltura, etc.) }\end{array}$ & & & & & \\
\hline $\begin{array}{l}\text { v.Videos with captions } \\
\text { w.Verify that external internet } \\
\text { sites/databases have accessibility } \\
\text { statements on their sites to } \\
\text { students with disabilities }\end{array}$ & & & & & \\
\hline $\begin{array}{l}\text { x. Provide an accessibility } \\
\text { statement that third party apps } \\
\text { used in your course are accessible } \\
\text { to students with disabilities. }\end{array}$ & & & & & \\
\hline $\begin{array}{l}\text { y. Statement on your syllabus } \\
\text { regarding disability } \\
\text { accommodations }\end{array}$ & & & & & \\
\hline
\end{tabular}

\begin{tabular}{|l|l|l|l|l|l|}
\hline $\begin{array}{l}\text { The biggest limitations to } \\
\text { making your online courses fully } \\
\text { accessible? }\end{array}$ & $\begin{array}{l}\text { Strongly } \\
\text { Disagree }\end{array}$ & Disagree & $\begin{array}{l}\text { Neither } \\
\text { Agree or } \\
\text { Disagree }\end{array}$ & Agree & $\begin{array}{l}\text { Strongly } \\
\text { Agree }\end{array}$ \\
\hline \multicolumn{1}{|c|}{ Challenges to Application/Practice } \\
\hline $\begin{array}{l}\text { 1. Time for designing online } \\
\text { content }\end{array}$ & & & & & \\
\hline 2. Time to attend training & & & & & \\
\hline $\begin{array}{l}\text { 3. Training and knowledge on } \\
\text { accessibility issues. }\end{array}$ & & & & & \\
\hline $\begin{array}{l}\text { 4. Training and knowledge on } \\
\text { needs of students with } \\
\text { disabilities }\end{array}$ & & & & & \\
\hline $\begin{array}{l}\text { 5. Tools to make the necessary } \\
\text { changes (software to assist } \\
\text { with transcripts, etc.). }\end{array}$ & & & & & \\
\hline $\begin{array}{l}\text { 6. Training and knowledge on } \\
\text { the types of changes that } \\
\text { need to be made }\end{array}$ & & & & & \\
\hline
\end{tabular}


Accessibility Professional Development

\begin{tabular}{|l|l|l|l|l|l|}
\hline $\begin{array}{l}\text { How important would the } \\
\text { professional development } \\
\text { opportunities be in assisting } \\
\text { you to accommodate online } \\
\text { students with disabilities? }\end{array}$ & $\begin{array}{l}\text { Not } \\
\text { Important }\end{array}$ & $\begin{array}{l}\text { Slightly } \\
\text { Important }\end{array}$ & $\begin{array}{l}\text { Moderatel } \\
\text { Important } \\
\text { Important }\end{array}$ & Very \\
\hline \multicolumn{2}{|c|}{ Institutional/Technology Support } & Important \\
\hline $\begin{array}{l}\text { a. Using technology to teach } \\
\text { students with disabilities }\end{array}$ & & & & \\
\hline $\begin{array}{l}\text { b. Assistance from (Online } \\
\text { Programs, Center for } \\
\text { Teaching and Learning, } \\
\text { Instructional Designer, etc.) } \\
\text { in adapting your online } \\
\text { course }\end{array}$ & & & & & \\
\hline $\begin{array}{l}\text { c. Using Universal Design in } \\
\text { instruction }\end{array}$ & & & & \\
\hline d. Using WCAG Guidelines & & & & \\
\hline $\begin{array}{l}\text { e. Training on ADA and 504 } \\
\text { regulations/laws }\end{array}$ & & & & & \\
\hline f. Training in Section 508 & & & & & \\
\hline $\begin{array}{l}\text { g. Video captioning } \\
\text { (YouTube, Screencasts, } \\
\text { etc.) }\end{array}$ & & & & & \\
\hline $\begin{array}{l}\text { h. Training on the policies and } \\
\text { procedures for students with } \\
\text { disabilities }\end{array}$ & & & & & \\
\hline $\begin{array}{l}\text { i. Teaching Blind or visually } \\
\text { impaired students }\end{array}$ & & & & \\
\hline $\begin{array}{l}\text { j. Teaching Deaf or hearing } \\
\text { impaired students }\end{array}$ & & & & \\
\hline $\begin{array}{l}\text { k. Teaching Cognitively } \\
\text { impaired students }\end{array}$ & & & & \\
\hline
\end{tabular}

What other feedback do you have regarding accessible design in your online courses? What other support would be helpful in assisting you in designing and implementing an accessible online course?

\section{Demographic Information}

For each of the following, please click the response that best describes you.

1. My gender:

Male

Female

Transgender

Gender Variant/Non-Conforming 
Not listed

Prefer not to answer

2. My age range:

21-30

$31-40$

$41-50$

$51-60$

Over 61

3. Number of years as a faculty at this institution:

$0-5$ years

6-10 years

$11-15$ years

16-20 years

Over 20 years

4. My highest degree is:

Master's degree

Education Specialist (Ed.S.

Doctorate (PhD.), (EdD.)

5. My current faculty status is:

Professor

Associate Professor

Assistant Professor

Instructor

Adjunct

Clinical Faculty

Not listed

6. Primary Level of Teaching (Choose one)

Undergraduate

Masters

Doctoral

\section{Primary Online Delivery Method (Choose one)}

Web-enhanced

(Traditional classroom setting. Traditional synchronous in-seat class that is enriched by the addition of an online component and require that students be actively engaged in that online component.)

Blended/hybrid

Asynchronous Online

Synchronous Online

Other 
8. How long have you been teaching online?

$0-2$ years

3-5 years

6-10

Over 10 years

9. For which disability or disabilities have you provided accommodation in your online class? Autism Spectrum Disorder (social interaction, communication, restricted interests and repetitive behaviors)

Cognitive Impairment (communication, social skills, self-directed)

Hearing Impairment

Mental health conditions (bipolar disorder, depression, schizophrenia, anxiety and personality disorders)

Physical disability

Vision Impairment

Other

None

\section{Training History}

10. How many total training sessions related to online learning have you attended in the past year?

0

$1-3$

4-8

$9-15$

$16+$

11. How many communication messages (email, bulletin board, listserve, announcements, newsletters) have you received from your institution regarding online training offerings?

0

$1-3$

4-7

$8-12$

$13-17$

$18-24$

$25+$

12. How much money do you spend on training and development, either sponsored or nonsponsored by your institution?

100 or less

101 to 500

501 to 1000

1001 to 2000

2001 or more 